\title{
Innovations Management: Case Study of Kazakhstan
}

\author{
R. Sagiyeva ${ }^{1}$, A. Zhuparova ${ }^{1}$, K. Alenova ${ }^{2}$ \& A. Galymkair ${ }^{1}$ \\ ${ }^{1}$ Al-Farabi Kazakh National University, Kazakhstan \\ ${ }^{2}$ Kazakh Agrarian University, Kazakhstan \\ Correspondence: A. Zhuparova, Al-Farabi Kazakh National University, Kazakhstan. E-mail: aziza_z@mail.ru
}

Received: June 21, 2014 Accepted: September 28, 2014 Online Published: December 20, 2014

doi:10.5539/ass.v11n2p69

URL: http://dx.doi.org/10.5539/ass.v11n2p69

\begin{abstract}
The article raises problems of innovative development of Kazakhstan in the light of the implementation of the adopted in the country programs of industrial-innovative development. According to the authors, a critical factor impeding the development of innovation in our country is failures in the management of innovation processes that require immediate correction.
\end{abstract}

Keywords: Kazakhstan, innovation management, innovation process

\section{Introduction}

Development of a knowledge-based economy in our country-is one of the key priorities set by the President of the Republic of Kazakhstan, Nursultan Nazarbayev, in the strategy "Kazakhstan-2050". This long-term goal is promoted by the trends observed in the modern world, which at this stage have amassed sufficient scientific, technical and socio-economic potential for transition to a new technological level. Today it is possible to outline the most important components of the knowledge-based economy:

1) The main factor and growth driver of the knowledge-based economy is the new knowledge and innovation embodied as in new products and services, so in advanced technologies. Considerable part of the GNP of developed countries is formed by the innovation sector, which not only develops dynamically, but also provides influx of multi-billions incomes through the external sales of innovations, educational and consulting services.

2) The comprehensive national innovation system works on commercialization and generation of scientific research. It provides continuity of innovation development of economy. The main elements of the innovation infrastructure are the universities and research institutions in cooperation with business, including transnational corporations.

3) The successful development of innovation economy is provided by the formed institutional structure that combines government regulation and market competitive forces. As a rule, the basic methods of state management of innovation processes aimed at creating a competitive environment not only for scientists, inventors and entrepreneurs, but also for domestic business, in order to arouse their innovative interests. A very important aspect of the knowledge-based economy-is the protection of intellectual property rights and the possibility of its inclusion into commercial turnover.

As Kazakhstan has identified the development of innovative economy as the most important strategic goal for quite some time, so at this stage we can evaluate some achievements of the state innovation policy.

\section{Literature Review}

We use the term of 'technology' and 'technological management', 'innovation' and 'innovation management' as part of organisational behaviour sometimes without much consideration what these notions imply. However, we want to ask what technology and its management are? We start our research with looking into the essence of technology and its managements and this way trying to understand our study better.

In literature, the definition of Abetti (1989) is widely used to define technology as "a body of knowledge, tools, and techniques, derived from both science and practical experience, that is used in the development, design, production, and application of products, processes, systems, and services" (cited from Tyler \& Steensma, 1998, p. 941). In other words, technology not only entails new product innovations and new processes by which outputs are generated, but also includes scientific and practical know-how that comes with experience. 
Technology often refers to new and better ways of achieving economic ends that contribute to economic development (Phillips et al., 1994). Through transfer technology contributes to the change and this change fuels economic growth via productivity increases (Benedetto et al., 2003; Ming \& Xing, 1999).Thus, by technology is broadly understood know-how, techniques, patented or otherwise proprietary processed, materials, equipment, or systems (Siegel et al., 1995).

Harris et al. (1996) identify four technology categories. In the first place is a key technology, one that is a competitive differentiator and, as such, belongs at the top of the scale. Then stands an emerging technology, one that has the potential to become a competitive differentiator (i.e. key) and is thus one step lower. Next down is basic technology, one that is required in order to be in the business but that is in no way a source of competitive advantage. Lastly, at the bottom of the scale, are commodity technologies, ones that are readily available in the marketplace for any and all customers.

Burgess et al. (1997, p. 323) refer to Samson (1991) who classifies technologies as product and process related and further subdivides them into hardware and software. Hardware process technologies include plant and equipment, whereas software process technologies encompass production management methods. Bento et al. (2004) go further than hardware and software and define non-codified skills and executive capacity as tacit wetware.

Close to this differentiation stands Farhang's clarification (1997) whose definition of industrial technologies comprise two parts: engineering documentation (quantum of knowledge by which such inputs as patent rights, scientific principles and R\&D are translated into production) and the manufacturing techniques (marketable industrial materials, components, and end-products). The latter, are human implementations of the written instructions contained in the former. Transfer of technology in cases of manufacturing process requires the transfer of technical knowledge in the form of process sheets, blueprints, products and material specifications, as well as "transfer of know-how of high-calibre engineering and technical personnel" (Farhang, 1997).

Metcalfe (1997) underlines the differences between science, technology and innovation emphasizing that technology involves much more than science, and innovation involves much more than technology. By Metcalfe (1997) science and technology are largely independent but mutually beneficial bodies of knowledge, created by different processes of accumulation within distinctly different communities located in different institutional contexts. Science is naturally academic and its legitimate output is additions to the existing stock of knowledge. Science is open, the output are widely diffused in international publications. Science is mostly lying alongside the development process and is used when needed (Jorde \& Teece, 1990). Technology in the words of Metcalfe (1997) is a distinctive body of knowledge with its own operating principles and norms for design activity. If science is open, technology is closed with quite different publication practices and a natural concern for secrecy or patent protection when private property rights are involved. Technology is naturally practical; its legitimate outputs are artifacts. The means, by which technological artifacts designed, constructed and operated intrinsic worth-are to be judged by the truthfulness of the knowledge but by its practical utility.

Technology itself is of no significance unless it is translated into innovations, which are subsequently diffused into economies, with the social and economic consequences being dependent on the degree of diffusion. Although, behind innovation is not only technology but marketing knowledge and production capability, and effective innovation always requires responses from users as well as suppliers. In the words of Jorde and Teece (1990, p. 78) "design is often at the center of the innovation process. Research is often spawned by the problems associated with trying to get the design right".

To describe the innovation process, the notions of learning and knowledge creation are often used in the literature. Nonaka and Takeuchi (1995) underline that companies innovate through a constant learning process generating new technological knowledge. According to Yakhlef (2005) successful product development, for example, requires component knowledge (knowledge about each of the core design concepts and the way in which they are implemented in a particular component) and architectural knowledge (knowledge about the ways in which components are integrated and linked together into a coherent whole).

Metaxiotis et al. (2005) link innovation to "new knowledge" or new constructed knowledge by showing how tacit knowledge can become explicit knowledge. "Firm knowledge" may exist as tacit knowledge (know-how) and/or explicit knowledge (know-what). 'Know-how' is understood as the procedural knowledge and 'know-what' as declarative knowledge (Assudani, 2005). Explicit or codified knowledge refers to knowledge that is transmittable in the language. Tacit knowledge, on the contrary, being hard to formalise, is a source for sustainable competitive advantage. 
Assudani (2005) suggests differentiating "knowledge of" and "knowledge from" notions. "Knowledge of" the firm is those that exist at the individual level, at the collective level, at the physical artefact level, at the firm level, and at the inter-organisational level. "Knowledge from" the firm is those that created in the form of innovations and organisational learning. Knowledge is seen by Assudani (2005) as a process of leveraging the firm resources for generating economic rents and for innovations-it is the process of leveraging "knowledge of" to generate "knowledge from" the firm.

Close to Assudani (2005), Nieto (2004) clarifying notions of the technological processes defines technology as a "stock magnitude", and technological innovation as a "flow of magnitude". The former is the output and the principal input of the innovation process and reflects the volume knowledge, competencies and capabilities that the company possesses at a given moment in time. The latter is a learning process in companies through which a flow of new knowledge competencies and capabilities are generated and technological advances are produced.

It is widely known, that technologies can be gained in three ways through purchasing, transferring or developing (Hong, 1994). Transferring production techniques costs money at the beginning yet makes less of a contribution than developing one's own techniques; however, it is more than purchasing new techniques. Developing new techniques also costs money, but it makes the greatest contribution to social and economic developments in the long run.

The facets of technology development and its further transfers are mostly managed on the technological and innovation concepts that are often used interchangeably. A distinction between technological management, management of technology, and R\&D management is given by Chanaron and Jolly (1999, p. 615) who conclude that:

1) $R \& D$ management is mainly to optimize the $R \& D$ budget;

2) management of technology (MOT) is to get the best fit with the firm strategy \& the best return on the technology portfolio; and

$3)$ technological management is to understand and control the impact of technology on all management functions.

In the 1960s and 1970s, in-house R\&D was considered the main source of technological innovation. Kiella and Golhar (1997) study the "total quality management" in R\&D environment and emphasise the distinction of two processes in acronyms as follows. In the R\&D work environment, when research is with the "Capital R" and development is with the "small d" (R\&D), invention is the desired outcome. On the other hand, R\&D is the process by which select inventions are developed into innovation, products for the marketplace. Research activities are managed increasingly at corporate level, whereas development activities are carried out and controlled at business unit level (Cavone et al., 2000).

Cavone et al. (2000) clarifying R\&D divide as an example programs of experimentation, the primary aim of which is to seek opportunities, programs of exploitation, and the effective use of given resources. Key characteristics of experimentation programs are a continuous search for new techno-organisational solutions, and a learning process aimed at enhancing the firm's knowledge base in the long term. Exploitation programs aim to create value through current activities, and to innovate by exploiting the skills embedded in a firm's human resources and technical systems in the short term. Therefore, exploitation programs seek to identify and use the potential of the current paradigm, while experimentation programs aim to identify and define the future paradigm.

Research in organisational theory (Serapio \& Hayashi, 2004; Yakhlef, 2005) have featured two competing paradigms that guide the way in which organisations manage their innovation and co-ordinate their R\&D activities. One school of thoughts contends that the organisation of the R\&D department is the target of increased centralisation, while the other maintains that the same function is being increasingly decentralised and contracted out to various partners and customers.

The move from R\&D management to MOT is related to the changes in the understanding of the source of technology, and therefore of technological opportunities, and in the upgrading status from operational to a more strategic positioning. MOT was developed in the mid-1980s. Chanaron and Jolly (1999, pp. 613-614) describing its tasks, refer to the National Research Council of the USA which states: "The MOT links engineering, science and management disciplines to plan, develop, and implement technological capabilities to shape and accomplish the strategic and operational objectives of an organization".

Technological management, in its turn, is using technology to leverage all functions within the company. It perceives technology as an impacting variable and a major resource for all management functions as a producer, 
a customer or a user. The scope of these branches is also different. R\&D management deals with evaluations and selections of R\&D projects and programs. MOT views technology portfolio and deals with forecasting, scanning, acquisition, exploitation, dissemination, commercialisation, transfer, and implementation of technologies. Technological management looks at technology as input, capturing and controlling its impact on every management field including marketing, human resource management, and strategy.

In traditional description of the innovation process it is common to break the process down into a number of stages which evolve sequentially. The innovation process thus proceeds from $R \& D$ and design (R\&D management), to production and marketing (MOT), and finally to sales and service (technological management), each using distinct approaches.

Successful innovations (Teece, 1989) often require horizontal as well as vertical co-operation. Horizontal linkages can help reduce spill over externalities and unnecessary duplication of research efforts and can also assist in the definition of technical standards for systematic innovation. Companies can find partners at different stages of technological development, including search for, discovery, experimentation, development of technologies, products and/or services and their production in organisational structures (Carneiro, 2006) upon new business models (Chesbrough, 2003). Today the management of innovations and technologies is undergoing significant changes in response to growing pressures to accomplish more with fewer resources at a faster pace. $\mathrm{R} \& \mathrm{D}$ operations are being asked to increase output for the corporation that is more closely aligned to planned business; do more in new commercial areas to accommodate the defence conversion thrust; respond to new world-wide competition due to globalisation pressures (Harris et al., 1996).

Gaule in his book "Open innovation in action" $(2006$, pp. 33, 71) suggest 5Ps as "key considerations for the building and maintenance of an innovation strategy...a comprehensive aid to innovators at any organization...[that] enable you to marry your short-term steps to your long term strategies without missing any opportunities to create value". These are, namely (Gaule, 2009):

1) purpose (the strategic objectives being sought through use of innovation);

2) process (the methods and governance used to nurture and manage the portfolio of innovative ideas);

3) people (the relationships between different innovation leadership roles, the required competencies and the appropriate reward and recognition mechanisms);

4) partners (the appropriate use of partners and other external relationships);

5) performance (the processes used to measure the effectiveness of investment in innovation and venturing).

Using this framework as a tool to "put together a holistic, integrated innovation strategy" (Gaule, 2006, p. 33) in this study of Russian and Kazakhstan R\&D organisations we aim to understand what has changed with purpose, process, people, partners and performance attributes since 1990s, since the countries transformed from inaccessible to emerging economies.

\section{Results}

First, with the implementation of the Strategy of industrial and innovation development of RK, elements of the innovation infrastructure began to form in the country; innovation activity of enterprises began to rise in the regions. Today 9 technology parks, 5 national and 15 regional laboratories, 9 venture capital funds started working in Kazakhstan. Three design offices are created and creation of 2 more is planned: transport engineering (Astana) and mining and metallurgical equipment (Ust-Kamenogorsk), the oil and gas equipment (Petropavlovsk), agricultural engineering industry (Kokshetau), instrumentation (Almaty).

Second, the Law of RK of 2006 on State support of innovation activity became the legal basis for the development of innovative processes in the country. In 2009 there were introduced amendments and additions, extending the authority of such development institutions as JSC "Center for Engineering and Technology Transfer", JSC "Science Foundation" and "KazAgro Innovation", JSC "National Innovation Fund". With the development of innovative processes in Kazakhstan and in connection with the need of solving new problems in the development of innovations, in January 2012 the Law of RK on State support of industrial innovation activity was adopted. It is intended to establish the legal, economic and organizational frameworks of stimulation of the industrial innovation activity, and determinate the measures of its state support. In particular, the new legislation is oriented to stimulation of the subjects of industrial innovation activity for the development of national high-tech and competitive industries and their export potential. Also, this law specifies the competence and authority of the government and other authorized bodies, and the subjects of innovation activity. It is remarkable that along with the authorized bodies such as the National Institutes of state planning and 
development, the New Law prescribes the competence of regional executive bodies in the sphere of industrial-innovative development. Considering the need to get results from innovation activity, the New Law not only clarifies elements of industrial innovation infrastructure and their functions, but also calls instruments and financial-institutional mechanisms of state support of innovation activity. Thus, in Kazakhstan are appearing elements of the systematic legislative framework for the realization of all stages of innovation activity and measures of its state support. Also there is legal and regulatory framework governing the conditions for the creation of innovative enterprises and the relationship between the subjects of innovation infrastructure.

Third, for the purpose to form in Kazakhstan the national innovation system of market-type and develop the competitive market knowledge, the transformation of leading universities into research universities begun. The presence of such universities helps to concentrate financial, material and human resources to the solution of major scientific and technical problems. Therefore, according to the new Law of the RK on Science and amendments to the Law on Education these types of higher education institutions as a national research university, national university, research university, university, academy, and institute begin to develop. In addition, research universities are called to implement the development program for five years, approved by the Government of Kazakhstan, and also have the opportunity to develop educational programs, using the results of fundamental and applied research with the aim to the generate and transfer new knowledge.

Feasibility provided by the legislation for creating the innovative educational consortiums became the most important mechanism of the formation of innovation infrastructure in Kazakhstan. This-is voluntary equitable associations acting on the basis of agreement on joint activities in which higher education institutions, research organizations, and other entities engaged in the production sphere, combine intellectual, financial and other resources for the training of highly qualified specialists on the basis of fundamental and applied scientific research and technological innovation.

It is innovative and educational consortiums that in prospect will allow integrating education, science and industry through the creation around the universities the area of research organizations, ensuring educational process by new knowledge.

Fourth, a significant step in the development of the national innovation system is a model of management of research activities embedded in the new Law of RK on Science, which increases the role of scientists in decision-making, eliminates unnecessary bureaucratic units and divides strategic, administrative and expert functions. For this purpose the powers of the High Science and Technology Commission under the Government of the Republic of Kazakhstan significantly expanded, where the leading scientists of the country are presented and which identifies as priorities for the science development, so the direction of its financing. National Science Councils created on braches of knowledge and formed by a number of local and foreign scientists are intended to occupy a key place in the final decision-making on the implementation of specific scientific projects and programs. In this connection, the decisions of the National Research Council became binding for the authorized bodies-the Ministry of Education and Science of RK, other ministries, coordinating research: health, agriculture, etc. The role of the scientific and technical expertise increases at the National Center of State Scientific and Technical Expertise (NCSSTE), which presents its results directly to the National Research Council. Also, in the new Law of RK on Science new mechanisms for research financing are identified. Now it is realized in three forms: grant, base and target-oriented (Mutanov, 2012).

Despite a series of unprecedented measures accepted in Kazakhstan on the way to the knowledge-based economy, we would like to highlight some of the systemic failings in the management of innovation, which have been identified by experts of United Nations Economic Commission for Europe and reflected in the innovation development review of Kazakhstan in 2012. In particular, the following managerial barriers are distinguished:

1) persistent verticality of innovation management: they are initiated by the state "from the top" with weak horizontal links between the elements of innovation infrastructure;

2) low commercial orientation of public research segments;

3) underdeveloped scientific base and human resources, their fragmentation and duplication of research;

4) the generating processes of new knowledge are structurally and functionally separated from the processes of its commercialization and deployment into production, i.e. there is no integrative connection between stages of the innovation life cycle;

5) business does not show interest to innovations because the role of branches with low knowledge intensity (raw sector) with rather high profitability prevails in national economy;

6) regional and branch mismatch of management of innovative processes. 
According to analysts, failures of the innovation management have the key reason: persistent verticality of management structures at low demand for innovation from the business, which is not stimulated by a competition. Actually high-quality transition was not made to market mechanisms of creation and development of innovations which are objective driving forces of innovative development of the companies. Thus, innovative initiatives "from the top"-from the state-were found non-demanded "at the bottom" by companies and consumers.

Besides the lack of objective competitive forces for activation of innovations in the country, administrative mistakes are observed at realization of each stage of innovation life cycle, which, as we know, in its traditional model contains stages of ideas generation, the basic and applied scientific research, developmental works and innovation commercialization with the subsequent transition to commercial development. In fact, at more detailed study of the practice of innovative development of Kazakhstan, classical management functions containing such basic elements as planning, organization, control, motivation, regulation and coordination at every stage of the innovation life cycle are not being fully realized. If it is possible to trace the functions of planning, organization and control at the stage of ideas generating, so the function of motivation, regulation and coordination are implemented poorly. For example, there are still no clear legal mechanisms for the protection and inclusion of intellectual property objects in economic turnover. Also there is duplication of directions and subjects of research studies in separated Scientific Research Institutes and universities in the rising personnel "famine."

If to pass to the analysis of the existing processes of innovation management in our country at the macro level, it can be stated that the functions of planning, organization, regulation and coordination of all phases of the innovation life cycle are divided between two leading ministries: Ministry of Education and Science of the Republic of Kazakhstan and Ministry of Industry and New Technologies of the Republic of Kazakhstan, and also carried out in parallel with other sectorial ministries. The control is not specifically attached to any particular government agency, and therefore responsibility for the results of innovation is blurred. Who (which organization or entity) to whom (what organization or structure) is responsible for the failed or implemented innovative projects? A special place in this whole mess is occupied by financing innovation processes that are carried out by various funds and development institutions, again, with uncertain responsibility for the results.

In the planned economy, as we know, there was a logical completeness of vertically organized management structure, and the "fulfillment of the state plan was the law" with all functioning measures of control and responsibility. Today symbiosis of state innovation initiative in conjunction with absent entrepreneurial dynamism demonstrates mistakes in the management of innovation processes, in which the functions of elements coordination of innovation infrastructure, control, responsibility, motivation and communication are not realized.

Each of the above-mentioned components of innovation management provides the necessary result of the whole controlled process, so the absence or neglect of one of the elements not only violates the integrity of the management system, but also leads to unexpected results. These results are unexpected because the innovation process is connected with specific factors such as:

1) spontaneous formation of new knowledge;

2) lack of information about the opportunities and risks of implementation and application of innovation;

3) the need for long-term investment resources.

With the transition of developed countries to the post-stage, the above-listed factors are complemented by such features as:

4) availability of vast amounts of knowledge and information;

5) rapid technological change (reduction of technologies life span);

6) wide spread of information technologies in all spheres of public life;

7) high level of innovation complexity, which requires a highly skilled personnel.

\section{Discussion}

Thus, it is reasonable to correct innovation management in Kazakhstan not only in accordance with the identified system mistakes, but also taking into account the above-listed factors.

What do we offer to do and how?

For normalization of the national innovation policy and in order to save resources, it is necessary to create a national agency-the Office of innovative development of Kazakhstan under the President of the RK. This 
institution is aimed not only to build innovative priorities of the country, but perform all the functions of innovation management at the macro level: planning, organization, regulation, motivation, control and coordination. This office is authorized to determine responsible sectoral structures for the results of innovation activity and develop the strategic program of regional innovation clustering. In its turn, strategy of the regional innovation clustering involves not only the use of natural and geographical potential of the territory, but also the creation of all the necessary missing basic elements of innovation infrastructure around universities. Hundreds of scientific-research institutes and small start-up companies that are directly related to the business should operate in the orbit of major regional universities. Under the leadership of this body recommendations about mechanisms of state-private partnership in the sphere of innovations, and also the relevant draft legislation are developed.

For successful clustering we consider that it is reasonable to use the ECM program "Information system "InnoMap.Kz" (map of innovative development of Kazakhstan), developed by scientists of Al-Farabi Kazakh National University. This electronic atlas allows in the regional context to determine the effectiveness of innovative development based on the use of three key criteria: performance of research activities in the region, the level of commercialization of new knowledge and total of innovation output per a unit cost.

Thus, the presented resource allows in dynamics to track intellectual activity in the region, market demand for the performed scientific research and also real innovative component of the gross regional product. Image integrity of an innovative development of country in comparison with the existing intellectual and natural potential allows not only systemically monitoring of relevant results, but also implementing the most effective management tools, as well as justifying the optimal integration interconnections for the development of innovative clusters.

\section{References}

Assudani, R. (2005). Catching the chameleon; understanding the elusive term "knowledge". Journal of Knowledge Management, 9(2), 31-44. http://dx.doi.org/10.1108/13673270510590209

Benedetto, A., Calantone, R., \& Zhang, C. (2003). International technology transfer. Model and exploratory study in the People's Republic of China. International Marketing review, 20(4), 446-462. http://dx.doi.org $/ 10.1108 / 02651330310485171$

Bento, E., Duarte, J., Heitor, M., \& Mitchell, W. (2004). Collaborative design and learning. Competitive building for innovation. Praeger, Westport.

Bryman, A. (2004). Social research methods. Oxford University Press, Oxford.

Bucknall, K. (1997). Why China has done better than Russia since 1989. International Journal of Social Economics, 24(7/8/9), 1023-1037. http://dx.doi.org/10.1108/03068299710178991

Burgess, T., \& Shaw, N. (2005). Organisational self-assessment and adoption of managerial innovations. International Journal of Productivity and Performance Management, 54(2), 98-112. http://dx.doi.org/10. $1108 / 17410400510576603$

Burgess, T., Gules, H., \& Tekin, M. (1997). Supply-chain collaboration and success in technology implementation. Integrated manufacturing Systems, 8(5), 323-332. http://dx.doi.org/10.1108/09576069710 179779

Carneiro, A. (2006). Adopting new technologies. Handbook of Business Strategy, 307-312. http://dx.doi.org/10. 1108/10775730610618981

Cavone, A., Chiesa, V., \& Manzini, R. (2000). Management styles in industrial R\&D organisations. European Journal of Innovation Management, 3(2), 59-71. http://dx.doi.org/10.1108/14601060010322275

Chanaron, J., \& Jolly, D. (1999). Technological management: expanding the perspective of management of technology. Management Decision, 37(8), 613-620. http://dx.doi.org/10.1108/00251749910291578

Chesbrough, H. (2003). Open Innovation. The New Imperative for Creating and Profiting from Technology. Harvard Business School Press, Boston, Massachusetts.

Chesbrough, H. (2006). Open Business Model: How to Thrive in the New Innovative Landscape. Harvard Business School Press: Boston.

Denzin, N., \& Lincoln, Y. (1994). Handbook of Qualitative Research. Sage Publications, USA.

Farhang, M. (1997). Managing technology transfer to China. Conceptual framework and operational guidelines'. International Marketing Review, 14(2), 92-106. http://dx.doi.org/10.1108/02651339710170195

Gaule, A. (2006). Open Innovation in Action: How to Be Strategic in the Search for New Sources of Value. 
London, UK.

Gaule, A. (2009). Open Innovation in Action: How to Be Strategic in the Search for New Sources of Value. In Proc. XX Int. ISPIM Conf. Open Innovation: Product and Process Innovation through Collaboration, Vienna: Austria.

Harris, R. C., Insinga, R. C., Morone, J., \& Werle, M. (1996). The virtual R\&D Laboratory. Research Technology Management, 39(2), 32-37.

Hong, J. (1994). Technology transfer and human resource development. Industrial and Commercial Training, 26(11), 17-21. http://dx.doi.org/10.1108/00197859410073754

Jorde, T. M., \& Teece, D. J. (1990). Innovation and co-operation: Implications for competition and antitrust. Journal of Economic Perspectives, 4(3), 75-96. http://dx.doi.org/10.1257/jep.4.3.75

Kiella, M., \& Golhar, D. (1997). Total quality management in an R\&D environment. International Journal of Operations \& Production Management, 17(2), 184-198. http://dx.doi.org/10.1108/01443579710158041

Metaxiotis, K., Ergazakis, K., \& Psarras, J. (2005). Dealing with the knowledge economy: Intellectual capital versus balanced scorecard. Journal of Intellectual Capital, 6(1), 8-27. http://dx.doi.org/10.1108/146919305 10574636

Metcalfe, J. S. (1997). Science policy and technology policy in a competitive economy. International Journal of Social Economics, 24(7/8/9), 723-740. http://dx.doi.org/10.1108/03068299710178801

Ming, W., \& Xing, Z. (1999). A new strategy of technology transfer to China. International Journal of Operations \& Production Management, 19(5/6), 527-537. http://dx.doi.org/10.1108/01443579910260856

Mutanov, G. M. (2012). Innovation: Creation and development. Almaty: Kazakh University.

Nieto, M. (2004). Basic propositions for the study of the technological innovation process in the firm. European Journal of Innovation Management, 7(4), 314-324. http://dx.doi.org/10.1108/14601060410565065

Nonaka, I., \& Takeuchi, H. (1995). The knowledge-creating company. How Japanese companies create the dynamics of innovation. Oxford University Press.

Nonaka, I., \& Toyama, R. (2003). The knowledge-creating theory revisited: Knowledge creation as a synthesising process. Knowledge Management Research \& Practice, 1(1), 2-12. http://dx.doi.org/10. 1057/palgrave.kmrp.8500001

Phillips, L., Calantone, R., \& Lee, M. (1994). International technology adoption. Behaviour structure, demand certainty and culture. Journal of Business and Industrial Marketing, 9(2), 16-28. http://dx.doi.org/10.11 08/08858629410059762

$S \& T$, Overview. (2006). Russia. Retrieved January 5, 2006, from http://www.globalwatchservice.com/Pages/ Russia/S\&T database

Serapio, M., \& Hayashi, T. (Eds.) (2004). Internalization of Research and Development and the Emergence of Global R\&D Networks. Elsevier, Oxford, UK.

Siegel, R., Hansen, S., \& Pellas, L. (1995). Accelerating the commercialisation of technology: Commercialisation through co-operation. Industrial Management \& Data Systems, 95(1), 18-26. http://dx.doi.org/10.1108/02635579510079425

Silverman, D. (2005). Doing qualitative research. Sage, UK.

Silverman, D. (2006). Interpreting Qualitative Data. Sage Publication, London.

Sister, V. (2006). Science complex of Moscow and the Moscow region-a basement of Russian innovation economy. Intellectual Property, 8, 411-26.

Teece, D. (1980). The diffusion of an administrative innovation. Management Science, 26(5), 464-470. http://dx.doi.org/10.1287/mnsc.26.5.464

Teece, D. (1989). Inter-organisational requirements of the innovation process. Managerial and Decision Economics (Special issue), 35-42.

The innovation development review of Kazakhstan of United Nations Economic Commission for Europe-New York, Geneva. (2012).

Tyler, B., \& Steensma, H. (1998). The effects of executives' experiences and perceptions on their assessment of potential technological alliances. Strategic Management Journal, 19, 939-965. http://dx.doi.org/10.1002/ 
(SICI)1097-0266(199810)19:10<939::AID-SMJ978>3.0.CO;2-Z

Tyler, B., \& Steensma, K. (1995). Evaluating technological collaborative opportunities: A cognitive modelling perspective. Strategic Management Journal, 16, 43-70. http://dx.doi.org/10.1002/smj.4250160917

Watkins, A. (2003). From knowledge to wealth: Transforming Russian science and technology for a modern knowledge economy. World Bank.

Yakhlef, A. (2005). Immobility of tacit knowledge and the displacement of the locus of innovation. European Journal of Innovation Management, 8(2), 227-239. http://dx.doi.org/10.1108/14601060510594684

Yin, R. (2003). Case Study Research: Design and Methods (3rd ed.). Thousand Oaks, Sage.

\section{Copyrights}

Copyright for this article is retained by the author(s), with first publication rights granted to the journal.

This is an open-access article distributed under the terms and conditions of the Creative Commons Attribution license (http://creativecommons.org/licenses/by/3.0/). 